\title{
Community Participation in the Implementation of Constitutional Laws through the Village Tourism Development in Tanjungsari County Rowosari Subdistrict Kendal
}

\author{
Suwarno Widodo \\ FPIPSKR Semarang PGRI University, Indonesia \\ Rosalina Ginting \\ FPIPSKR Semarang PGRI University, Indonesia \\ Supriyono P. S. \\ FPIPSKR Semarang PGRI University, Indonesia \\ R. Istiyaningsih \\ FPIPSKR Semarang PGRI University, Indonesia
}

Received: May 8, 2017 Accepted: October 16, 2017 Published: October 20, 2017

doi: 10.5296/jsss.v5i1.12016 URL: http://doi.org/10.5296/jsss.v5i1.12016

\begin{abstract}
The study was backed by the existence of equitable development and the acceleration efforts around countryside, has done several programs/activities at the village level -based community empowerment as well as optimize the local potential in the village such as tourist village. With the participation of the community directly in the tourist village development, then it can also be used for local community empowerment efforts. This research aim is to find the community participation in the legislation implementation through the Village tourism development Tanjungsari County of Rowosari Sub district Kendal. This research type is qualitative, descriptive research was carried out in the village in Kendal. Focus of the study
\end{abstract}


was excavation of the tourism potential village, forms management in the development of tourism and other forms of activities upon community participation through the development of village tourism. Data collection methods used is interviews, observation, documentations. Technique of data analysis applies qualitative approach. The results shows that the Tanjungsari Village developed into a decent Education about how to cultivate fish and make crafts calligraphy that has tourism potential among other industrial centers household processing and marketing Fish Boiled \& smoked fish, as well as the calligraphy craft. Tanjungsari Village Development model geared at empowering communities by involving the community in the development of tourist villages ranging from socialization and decision making in order to prepare the tourism components and the Pokdarwis formation. The research conclusion indicates that public participation can be rated high enough and enthusiastic but there has been no support program from the Government to prioritize the village tourism development. While the obstacles faced that there isn't law regulation because the tourist village development program is not yet contained in the RPJMDES and RKP village then be followed up with SK (Circulating Letter) Regent Tanjungsari assignment as rural education. It suggests that socialization program in order to disseminate the existence in Tanjungsari Village with invites schools to learn to cultivate fish, creating crafts calligraphy through website and social media.

Keywords: community participation, constitutional laws of village, village tourism

\section{Introduction}

Democratization at the local level became inevitability when areas such as (provinces, district and city) are given the authority of political openness and decentralization through the instrument of the regional head election directly (Constitutional Law No. 32 in 2004), then just wait for the time course of policy emergence so that the village also empowered politically and economically. Village ACT in 2014 explicitly translate alignments of State on empowering citizens and village as the entity that has the independence, so that the village can be the equivalent of dealing with the State interests (Government) and private (investor) interest.

Self-contained villages is currently an important issue since the Constitutional Law No $6 / 2014$ of the village, the main policy that brought the village fund allocation for which is estimated to range from 800 Million Rupiah until 1,4 billion rupiah for every village, the combined funding obtained from the National Budget, Regional Budget of Province and Regional Budget of district/city. The village fund allocation known as (ADD) the good from the Center as well as this Region can be utilized for the development of tourist villages of origin according to the rules that have been set. In this case the village is included in the empowerment of village community. Empowerment of village community can be done one of them with the potential local economic development including tourism village.

According to these problems and in line with the strategy and the policies as stated in Central Java province of RPJMD in 2013-2018, the next in order to combat poverty in rural Central Java province then developed the concept of Village Autonomy in the hope can be realized gradually in a span of 2015-2018. In order to speed up and equitable development in the country, has done several programs/activities at the level of village-based community empowerment as well as optimize the potential of the local in the village there is one of the 
programs/activities that have been and are being carried out in Central Java i.e. tourist village. One of the counties have program highlights in the development of tourism is a Government District of Kendal is planning on setting up 25 villages in order to become tourism village in 2016.

Kendal has many villages that could potentially be a tourist village that has stood relatively as many as popping up in Kendal, but yet everything is professionally managed and sustainable. In addition, many of which need to be addressed from both facilities and infrastructure side of the road, headed for the location and support facilities in the village itself. It is powered from the Central Java provincial government data (2014) about the problems faced in the tourist village of program execution, among others, have not been optimal management and innovation of tourist attractions in the village who put forward the elements culture as the main attraction and still low response of the community towards the village existence as a tourist attraction. The tourist village is expected to enhance the welfare of society, pressing unemployment and poverty.

Tanjungsari County of Rowosari sub district is one of the villages in the coastal area of Kendal which has tourism potential with soy and fish processing both of baked/roast, by the existence of a home industry and as many as 450 people processing and trade marketers of fish boiled with the capacity to produce an average of 12 tons of fish per day with a range of marketing that supplied to areas such as Kendal, Magelang, Temanggung, Wonosobo, Banjarnegara, and Semarang. Tanjungsari County potential if used as a tourist attraction attractive even developed and managed professionally then likely to be developed into a tourist village with the village of educational tours that can be offered to the traveler in the form of Live In or the feel of living in the place. So they really could be part of a community, living, dining, and activities together with residents in the Village as a home stay model and witness how to cultivate fish by way of roasted, and by means of smoked/baked goods.

The above conditions are a very potential in the development of community-based tourism (Community Based Tourism/CBT) which is the development concept of village tourism by involving local communities and put in place which has the authority to manage and develop its own regions to increase the welfare of local communities and the sustainability of local culture and natural resources. According to Suansri (2003: 14) "CBT is tourism which focuses on the sustainability of environmental, social, and culture into a single package. It is managed and owned by the community, for the community, with the aim of allowing visitors to increase their awareness and learning about the community and the local way of life ". This supported the United Nations World Tourism Organization (UNWTO) an encouraging Indonesia to further maximize the development of tourism-based village or tourist village.

In this study will be discussed about the work done, either by the Government or village community of Tanjungsari itself for community empowerment through the development of village tourism. The purpose of the development of tourism which involves the community of them namely, 1) empowering communities through the tourism construction, 2) improve the role and community participation in order to gain economic, social, and cultural tourism development of 3) provides an opportunity to all members of a balanced society, both men and women. It is therefore one of the approaches that are obtainable are used for community-based tourism development approach is participative (Demartoto, 2009). 


\section{MInstitute ${ }^{\text {Mink }}$}

The community will feel empowered to participate by having their involvement in all activities that take place in the tourist village. Society can engage participation in four stages, namely, the decision-making stage, the implementation stage, phase retrieval evaluation stage, and benefits. There are two forms of public participation that is an intangible participation (real) that includes the participation of fund, power, participation and participation skills, and participation that are intangible (abstract), namely participation of ideas, and participation in decision-making. Community participation in the development of village tourism is driven by several factors, namely, motivation and benefits expected program results utilizing the community together so that the community benefits from the program (Karianga, 2011). While according to Totok Mardikanto and Poerwoko Soebiato participation is defined as the participation of a person or a group of members of the public in an activity (Mardikanto \& Soebiato, 2013). The benefits obtained at through participation that can satisfy the interests of the local community (Ndraha, 1990). On the basis of this, researchers are interested in conducting research with the title "public participation in the implementation of the legislation through the development of Village tourism village In Tanjungsari County of Rowosari District Kendal”.

\section{Literature Review}

\subsection{Community Participation}

Dwiningrum (2011) in her book entitled Decentralization by citing the opinions of Cohen and Uphoff on the sense of participation, define that participation as the involvement in the process of decision making, program implementation, obtaining a benefit, and evaluating the program. In this study, the sense of participation is the active involvement of citizens in Tanjungsari County into village Development. The involvement of it in the form of activities of digging the potential, and develop tourism in Tanjung Sari County, which serves to prosper the surrounding communities.

The community role in the decision-making process of investigation by its nature is distinguished into two consultative and partnership. Participative pattern that typically utilized by consultative retrieval policies as a strategy to gain community support (public support). While the pattern of public participation which is a partnership with local community better appreciate giving the position or the position of the same group of decision makers. Because it is positioned as the second partner of different groups that discuss issues, find an alternative problem solving and making decisions together. Thus the decision not be sided the public or businessman, but together the community. The existence of this concept then there is an effort to redistribute the decision-making authority (Putra, 2015).

There are four stages in the public participation (Dwiningrum, 2011). First, participation in decision making of public participation in decision-making with regard to the determination of this alternative with the community to agree on a wide range of ideas related to the interests of collaborate. Second, participation into implementation, community participation in the program implementation is a continuation of the plan agreed upon earlier, both with regard to planning, implementation, as well as the destination. Third, participation in the taking of benefit, this participation is inseparable from the quality or quantity of program implementation results that can be achieved. Fourth, participation in the evaluation, this participation aims to find out if the program execution has been set out according to the plan. 
So that public participation must be through the four stages in order to make the goal of a program can be implemented.

According to Ericson (Slamet, 1994: 89) there are some forms of participation that can be given in a Community development program, i.e. participation of fund, possessions, participation, participation skills, social participation, participation in the decision-making process, and the representative participation. But generally can be grouped into two types, namely the participation given in tangible form (it has existed), such as fund, possessions and skills. While the second is a form of participation is given in the form are not real (abstract), namely in the form of participation of deep mind, social participation and the participation of the representative.

\subsection{Understanding the Tourism Village}

The notion expressed by tourism village Inskeep (1999: 166) mentions that the Village Tourism is where small groups of tourist stay in or near traditional, often remote villages and learn about village life and the local environment (rural tourism where a small group of tourists stay in or near the traditional atmosphere, often in remote villages and learn about rural life and local environment).

Tourist village is the village development that has tourism potential that are equipped with supporting facilities such as transportation and lodging. Meanwhile, according to Regulation of Minister of Culture and Tourism number: KM.18/HM.001/MKP/2011 About community empowerment Program Guidelines (PNPM) Independent of Tourism States that the village was a form of integration between attractions, accommodation and supporting facilities are presented in a structure of people's lives that blends with the Ordinances and tradition. So village tourism can be defined as a village which has tourism potential and have support facilities presented in a structure of community lives that are fused with tradition.

Nuryanti (1993), village tourism is a form of integration between attractions, accommodation, and facilities are presented in a structure of community lives that blends with the Ordinances and tradition. Within these limits the central role it once implied that the local community in presenting an integrated tourist attraction. So, the tourist village is an area of countryside which offers an overall atmosphere that reflects the authenticity of countryside, seen in terms of its cultural and social life, in daily customs, architecture and spatial structure of the village, as well as having the potential to be developed in the various components of tourism attractions, for example, food and beverage, souvenirs, and other tourist necessities.

\subsection{Village Tourism Development}

Development in Major Indonesian Language Dictionary is derived from the verb "evolved" which is meant: a) an open bloom, b) make great (broad, evenly), c) makes the forward (well, perfect) (Department of national education, 2005). So the development of tourist villages could be interpreted as making activities forward of a tourist village. According to the United Nations World Tourism Organization (UNWTO) encouraging Indonesia to further maximize the development of tourism-based village or tourist village. In addition to attracting more tourists, development of tourist village also provide equitable development up to the village level and raised the level of the community's economy. In addition, according to Putra and Pitana (2010) development of village tourism aims to involve the community in the 
development of tourism so that people with a culture not only become object but also village community should be aware of and want to improve themselves by using tourism as a tool both for the improvement of the welfare or preservation of cultural values as well as local customs.

The development of this tourist village is the realization implementation of the Regulation of the Minister of regional village development of the, Left, and transmigration of the Indonesia Republic number 4 in 2015 that govern Business Unit in the village of BUM can perform business activities alongside one of the village organizes a series of business from community groups; also the implementation regulation of the Minister of regional village development, Left, and transmigration No. 5 in 2015 that governs the priority utilizing of the village Fund to achieve the village development goals that is improving the society welfare and quality life of mankind as well as poverty reduction, in the form of the development potential of the local economy.

The village fund allocation known as (ADD) both of the Center as well as the region, can be utilized for the development of tourist villages of origin according to the rules that have been set. In this case the village is included the village community empowerment. This can be done one of them with the potential local economic development including tourism village. Refer to the definition of a tourist village, the villages that could be developed in the village will provide a good example for other villages, the determination of a village as part of a tourist village should meet the requirements, such as the following (Priasukmana and Mulyadin, 2001): a) accessibility well, so easily visited by tourists by using various types of transportation; b) have interesting objects in the form of nature, art and culture, legends, local food, and so on to be developed as a tourist attraction; c) community and village authorities to receive and provide support towards highest tourist village and tourists who came to this village; d) security at the village is assured; e) Available accommodation, telecommunications, and adequate workforce; f) cool temperate or colder; g) relate to the other attractions that are well known by the public at large.

Development of tourist villages had to be planned carefully in order to make the impact that arise can be controlled. Based on research and studies from the UNDP/WTO and some consultants, Indonesia reached the two approaches in drawing up the framework/concept development work from a village into a tourist village that is not direct Interaction with the approach and interaction and a half straight. Another alternative of this model is the incorporation of the first and second models. (UNDP and WTO. 1981. Tourism Development Plan for Nusa Tenggara, Indonesia. Madrid: World Tourism Organization. p. 69).

\section{Research Method}

In accordance with the problems presented, then the approach of this study is a descriptive qualitative research. A study that aims to be able to describe the real state of affairs in the field about the symptoms or phenomena that occur (Moleong, 1989: 77). Symptoms or phenomenon in question is public participation in the legislation implementation through the development of Village tourism in Tanjungsari County of Rowosari Sub District of Kendal. Focus or point attention in this research are explained in depth about how that included excavation of the village tourism potential, forms management in the development of tourism and activities other forms upon community participation through the development of village 


\section{Macrothink}

tourism.

Method of data collection in this research include: a) Interview, b), Observation c) Documentation. To give the definition of this data or the phenomena are discovered and collected in this study then conducted an analysis of empirical research with qualitative approach is descriptive. Researchers use triangulation validity inspection techniques data as data. When the researchers did a data collection with triangulation, and researchers gather data while testing the data credibility, checking the data credibility with data varieties of collection techniques and various data sources (Sugiyono, 2013). Data triangulation is defined as techniques of data collection that is combining the various techniques of data collection and existing data sources (Sugiyono, 2019).

\section{Result and Discussion}

The last result in this research is the location of Tanjungsari worthy to serve as the village, while the results from the community participation in the development of village tourism by planning a tourist village. To illustrate this, then do some analysis.

\subsection{Tanjungsari County Tourism Potential}

The potential attraction of Tanjungsari village is:

\section{1) Processing and Marketing Fish Boiled}

The majority of Tanjungsari village community dwellers that worked as an agent at once boiled fish marketers and smoke. The types of fish are usually boiled and the cob kites. There are approximately 450 people and processing trade of marketing range include Kendal, Magelang, Temanggung, Wonosobo, Banjarnegara and Semarang.
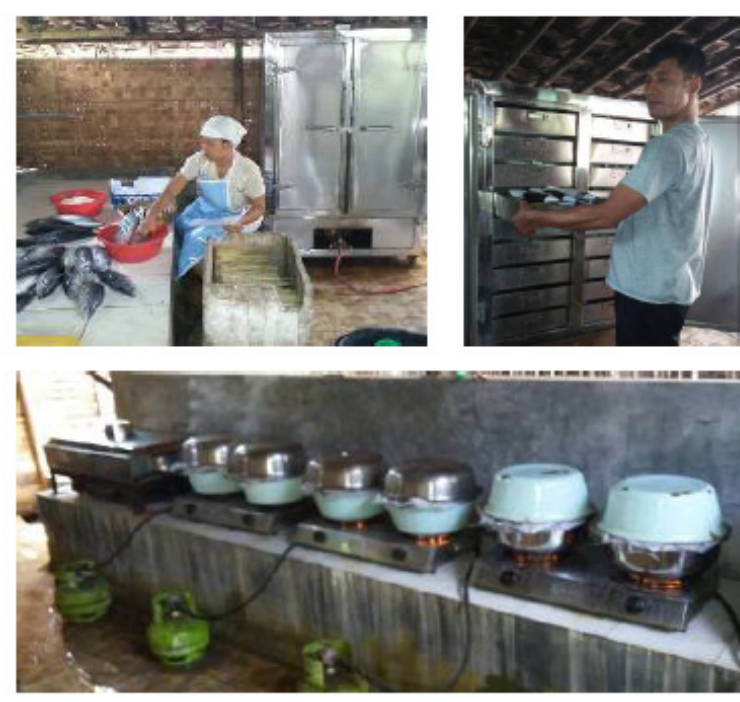

Figure 1. The potential of processing fish with soy

Source: Research Results.

2) The processing and Fish Marketing

Processing in addition to smoked fish by way of baked there are about 45 people to cultivate 


\section{Macrothink}

fish in ways smoked/baked goods. The type of fishes that was processed by way of fogging is Genjong, Pari, Pethek, sometimes Tongkol can also be processed in ways smoked. The marketing also has spread to the outer counties such as Temanggung, Wonosobo Semarang and Banjarnegara.
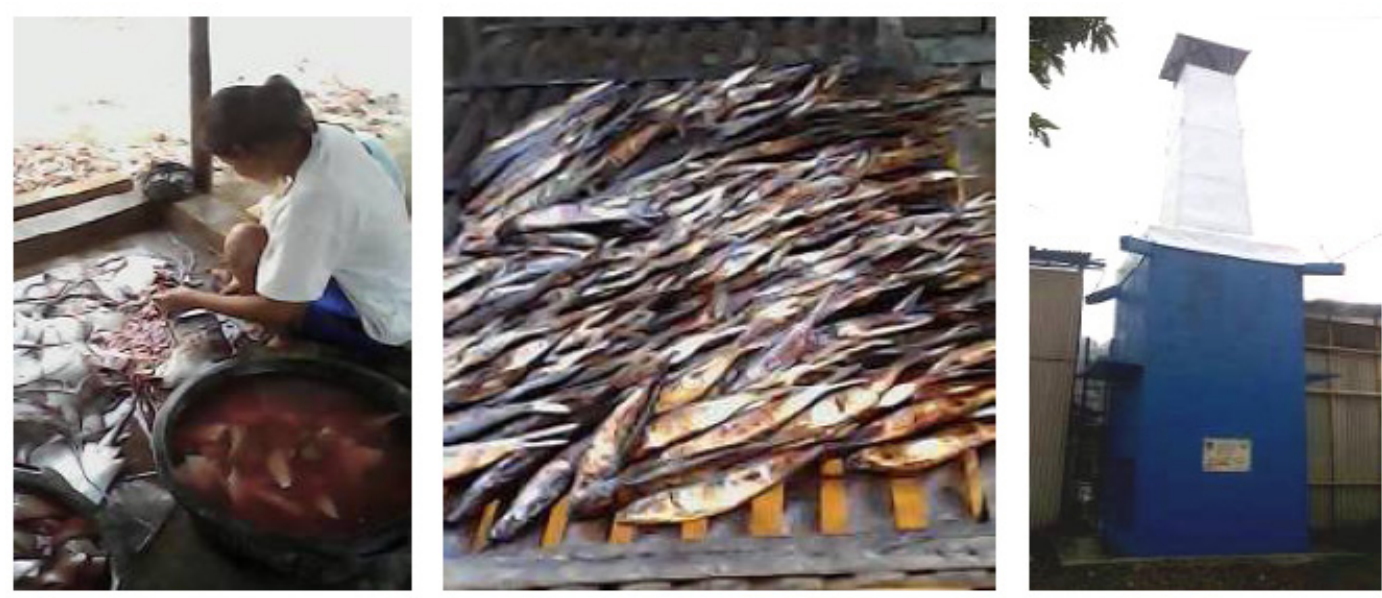

Figure 2. The processing potential of smoked fish

Source: Research Results.

3) The craft of Calligraphy

In Tanjungsari County there are 3 units making business calligraphy with a total workforce amount 45 persons, production of calligraphy from the Tanjungsari County marketed almost in all regions of the country. Power of marketing is done by the inhabitants of Tanjungsari County and some community around with worker come from some areas in Indonesia.

This effort also is advantaging because it has been proven to be able to lift the economy of the village community. Production calligraphy results of Tanjungsari County is also often on show in the exhibition events both local and provincial levels are present, such as at the village exhibition. 


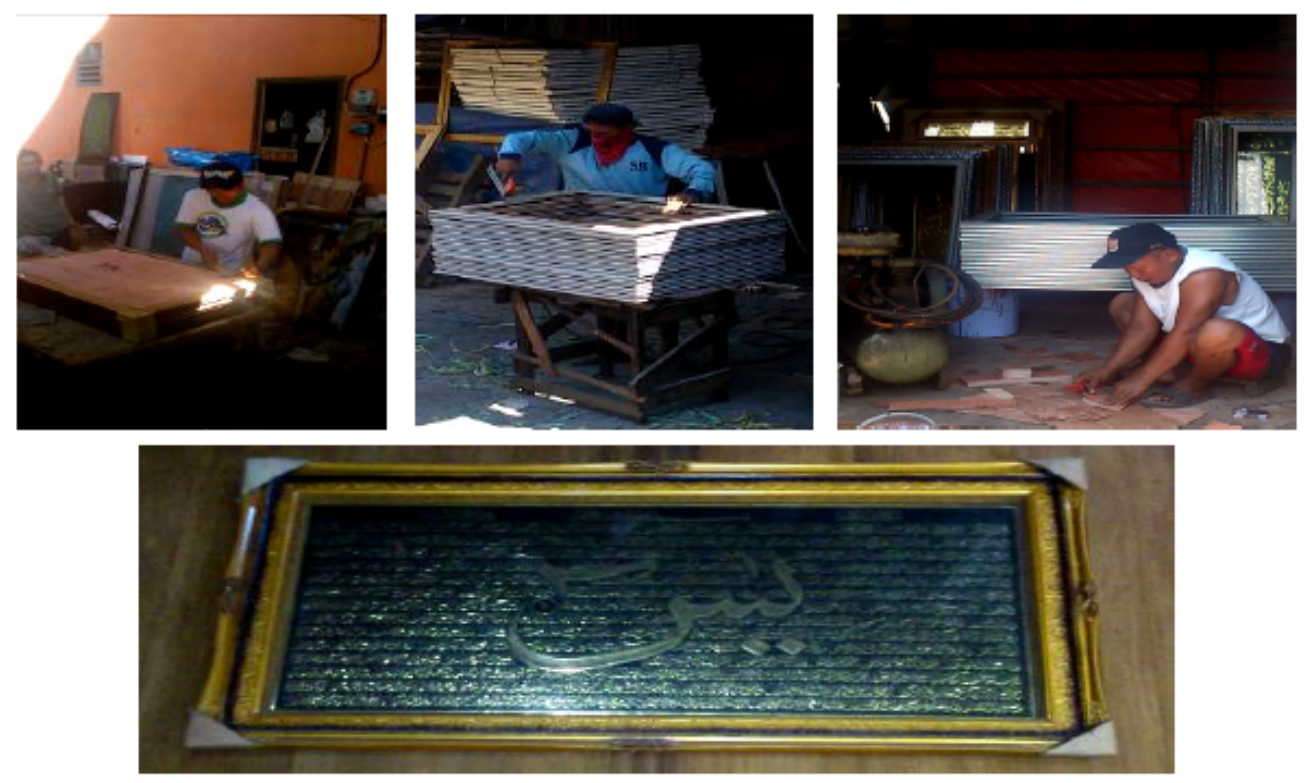

Figure 3. Potential crafts calligraphy

Source: Research Results.

In addition to being the central processing of fish grilled with soy and fish as well as craft calligraphy center, Tanjungsari County of Rowosari Sub-District also has other tourist potential, namely farming Carp fish /Nila, Village Agriculture Potential, The potential Field of Village Farms, Agate craft, Bonsai craft.

\subsection{Tanjungsari Village Development Direction}

1) Policies and development Model of Tanjungsari County

Tourism Development in a tourist destination should be based on the planning, development, and direction of a clear management so that all potential, a tourist destination can be used optimally to improve the society welfare. As for the direction to achieve wisdom tourist village in Tanjungsari County several things have been done by the Government with the assist of Tanjungsari County together with community leaders and local residents as follows.

Tanjungsari County development based on research results indicate the development direction of village tourism is still limited to the stage of the proposal have not yet focused on the planning stages through to implementation and continuation of the RJMDES tourism village because the village government focus is still directed to the implementation program of the home industry is working with the Ministry of Women's Empowerment, but it is also expected that later can be used in the framework of the components preparation of village tourism development.

In the development of tourist villages, community participation in decision making the tourism village. This is in accordance with the concept of a development policy retrieval starting from the bottom (bottom-up planning) in the implementation of the ACT. The involvement of local communities in the village tourism development is one of the main requirements in community concept-based development in accordance with the mandate of village ACT. Development model tourism village in Tanjungsari County is a model of 
community empowerment by involving the community in every stage of decision making.

Associated work program in relation to the development of village tourism, both RPJMDES, RKP village 2016-2020, Government Village, have started spends for empowerment activities such as BUMDES which is expected to be one of the components preparation of the continuation of village tourism development.

Whereas the appropriate allocation related Villages ACT mandate the village Fund known as (ADD) in Tanjungsari County yet focused to the village tourism development because the allocation is still focused on the improvement of the physical means of the village although it is expected that such activities can also be used as a component completion of the village tourism development.

Though not yet a tourist village in an RKP program in 2017 and also RPJMDES village but the Government is ready to commit the addition or RPJMDES revision in the middle of its implementation. Given the current development programs cannot be separated from RPJMDES and RKP village, and if the community supports the tourism village will be a program that continues to be sustainable.

2) The potential of education and Household Industrial of Fish Processing

Tourism potential which is relied upon in Tanjungsari County is the industrial sector of Household fish processing, because Tanjungsari County is also a line to Sendang Sikucing Shore, so that the focus of Tanjungsari County is educational tours on how to cultivate fish and how to make the craft of calligraphy and so on, because of the potential nature in this area is just a farm.

The potential industrial sector of Household Fish Processing of very large it is given most residents of Tanjungsari communities became businessmen home industry and in 2016 government programs have been implemented in order to build the household industry. This is in accordance with industry mentoring program household cooperation between of Semarang PGRI University in with BAPEDA of Kendal District.

Home industry is also expected to have a role in developing Tanjungsari County. Therefore the necessary breakthroughs are supporting tourism activities. Then the educational tours program in Tanjungsari can be offered in schools because currently many neighborhood-based school programs and local wisdom. That's what can be done to develop a tourist village.

The constraints of the establishment the tourism village is the juridical problems because it is not yet contained in the RPJMDES and RKP village, and then has not filed with Circulating Letter of Tanjungsari County assignment as a tourist village in order to back-up, follow up, equip Sendang Sikucing as excursions there need to be supported in the surrounding villages to become tourism village, which features a tour guide, cultural attractions, natural environment, food, and home stay. That means it could form a stub the village education which invites schools to learn to cultivate fish in advance for a year now, and next year could form a tourist village with equipped Sapta Pesona-driven society.

3.3 Community Participation in the Village Legislation Implementation through the of Village Tourism Development in Tanjungsari County

This research was carried out to find out which form of community participation in the 
Village Legislation implementation through the Village tourism development in Tanjungsari County. Public participation is community involvement in the program or what to do and how to do it. The involvement in the contributions forms in the activities that have been decided upon and utilize the results of these programs together.

Development of tourist villages of the community takes part in decision making the tourism village. This is in accordance with the concept of a development policy retrieval starting from the bottom (bottom-up planning) in the ACT implementation by strengthening community as a development subject through the basic settings of the village participation, i.e. are contributing actively to the village tourism development. The involvement of local communities in the village tourism development is one of the main requirements in the community concept- based development in accordance with the mandate of the village ACT.

As for participation that is already done in Tanjungsari County Development, among others, the following:

a. The Formation of Conscious Tourism Tourist

Village management system is based on with the management of Tanjungsari on society by forming a group conscious tourism. Preparation of the village in order to the development of village tourism is already up to the formation of the caretaker of Conscious Tourism Tourist known as Pokdarwis, who first conducted the excavation of village potentialities. To run the Organization of tourist villages and the Division of duties of each person who has been appointed, among others, Home Stay, food, Attractions/culture, environment/nature, Guides, marketing. Then after formed stewardship that will be registered into a tourism agency which will then get Circulating Letter known as SK.

b. Preparation Components of the tourist village

Community participation is also seen in Tanjungsari setup components of the tourist village, namely, accommodation and attractions. Accommodation in question is the completion of a portion of the dwelling place of the locals as a home stay and or units that develop over the living concept place of residents for tourist necessity. While the attractions prepared was totality of everyday Tanjungsari County residents who are mostly into fish processing trade soy and smoke along with the physical setting of the village location which allows tourists integration as active participation in educational tours, activities and attractions or cultural attraction and training in crafts and other things that are specific.

Planning accommodation tourist village that's already been done i.e. completion of procurement of home stay for tourists, with leased one or two rooms of the House residents, so it looks more natural and natural rural tourism.

While the arts and cultural attractions that are available to welcome the tourists in the form of artistry tambourine, the cultural attractions be shown each event race Selapanan Anjangsana. As for the form of artistic and cultural attractions that are prepared Tanjungsari community can be shown in the form of art, Baronang, Samprohan Sholawatan performed by women, and tambourine Duror teenagers.

As for the natural attractions are indeed still be limitations in Tanjungsari County because there is no natural tourism potential because it is only surrounded by rice fields and only fish farming ponds. 


\section{Macrothink}

Specifically the Groove tour or tour package has not yet been set, but there is already a description of objects or destinations to visit in the form of calligraphy crafts, a baked central and gift shop, educational tours area farming, cultivating bonsai as well as agate craft and cultivating of Carp and Nila fishes.

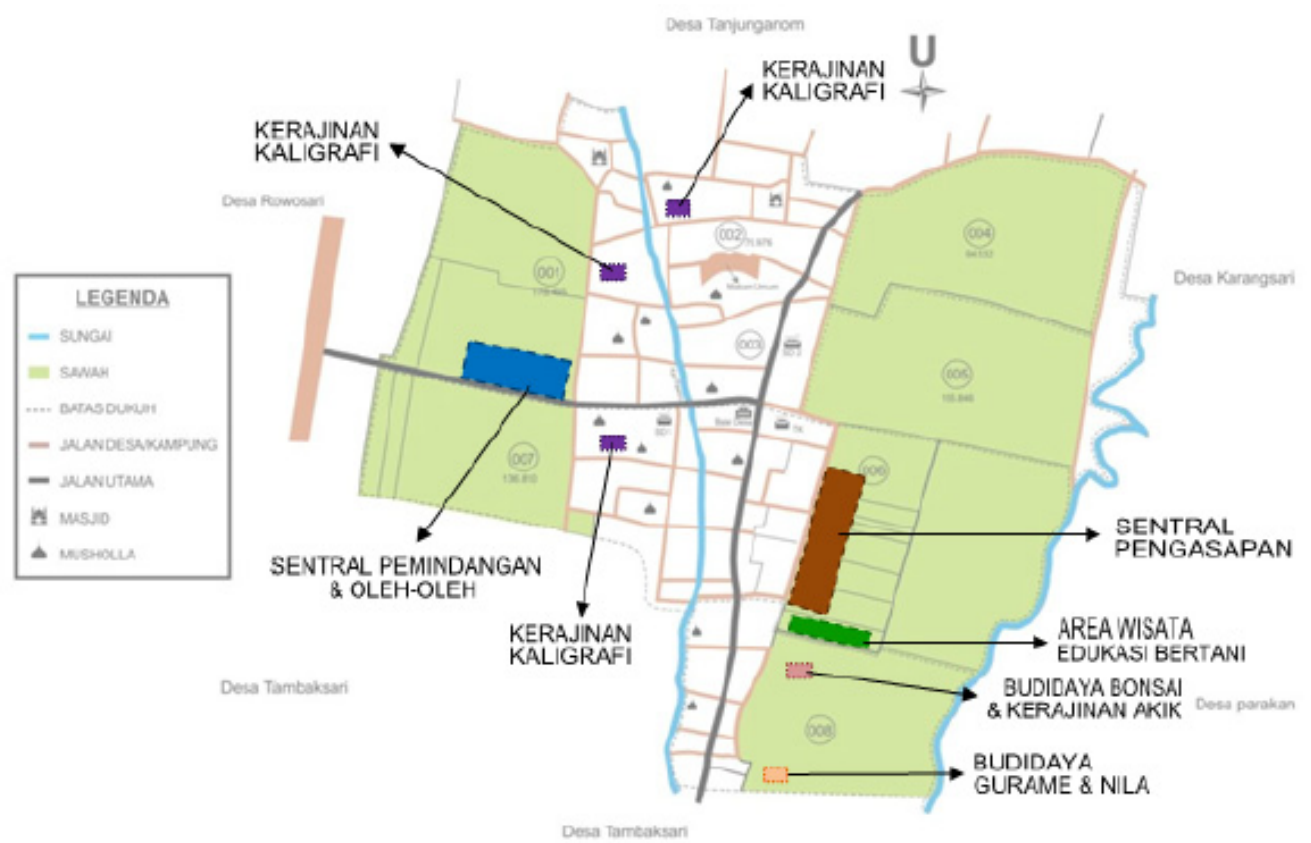

Figure 4. Tanjungsari village map

Source: Research Results.

\section{Conclusion and Suggestion}

Based on the research results and discussion, then things can be summed up as follows:

1) Tanjungsari County should be developed into a tourist village education relating how to cultivate fish and make calligraphy crafts that have tourism potential among other household industrial centers out of the fish processing and Fish baked and boiled marketing, as well as the calligraphy craft. A strategic location in line with Sendang Sikucing shoreline in Rowosari district potentially can be metropolitan place of fish industry with a major feature of the business activities of fisheries and fisheries processing that are able to serve and encourage development activities of fisheries in the surrounding area.

2) Development model of tourism village of Tanjungsari directed at empowerment by involving the community in the tourist villages development ranging from socializing and take a decision aiming to prepare components and formation of Conscious Tourism Tourist known as Pokdarwis tourism village. Community participation can be rated high enough and enthusiastic but there has been no support program from the Government to prioritize the village tourism development. Those are still limited to stage the proposals because the focus of the current village government runs the improvement of Household Industry program known as (IR) is expected to be followed up in order to realize a tourist village. 
3) Obstacles to the formation of village tourism is no law foundation because the tourist village development program is not yet contained in the RPJMDES and RKP village to can then be followed up with Circulating Letter known as SK of Tanjungsari County assignment as rural educational tours in order to support tourism activities in Sendang Sikucing area. The funds allocation are new to the dilution allocated infrastructure and community empowerment can be followed up with the allocation in the coming year for the formation aiming to create village education with the tourism potential of the Sapta Pesona relied upon.

\section{Suggestions}

1). The construction is specifically about the preparation of village tourism will generate communities competence and skills of to participate in the tourist village developing. They need training from tourism related guides, home stay and cultural attractions in order to prepare the components of the tourist village.

2). The need for socialization in order to disseminate the existence in Tanjungsari County by providing concrete evidence in the form of tourist maps, and tourism that flow in Tanjungsari County there are lots of potential educational tours that are interesting to visit. As for the form of all kind promotions, one of which with invites schools to learn how to cultivate fish, create calligraphy crafts through the website and social media.

\section{References}

Demartoto, A. (2009). Pembangunan Pariwisata Berbasis Masyarakat (Tourism Development Basically on Community). Surakarta: Sebelas Maret University Press

Pusat, B. D. (2005). Kamus Besar Bahasa Indonesia Edisi Ketiga (Indonesian Dictionary Third Edition). Jakarta: Balai Pustaka.

Dwiningrum, Siti Irine Astuti. (2011). Desentralisasi dan Partisipasi Masyarakat dalam Pedidikan (Decentralization and Community Participation on Education). Yogyakarta: Pustaka Pelajar.

Inskeep, E. (1991). Tourism Plannning "An Integrated and Sustainable Development Approach”. New York: Van Nostrand Reinhold.

Karianga, H. (2011). Partispasi Masyarakat dalam Pengelolaan Keuangan Daerah (Community Participation into Regional Fund Management). Bandung: PT Alumni.

Mardikanto, Totok dan Poerwoko Soebiato. (2013). Pemberdayaan Masyarakat Dalam Perspektif Kebijakan Publik (Community Empowerment into Public Policy Perspective). Bandung: Alfabeta.

Moleong, L. J. (2000). Metodologi Penelitian Kualitatif (Qualitative Research Methodology). Bandung: PT Remaja Rosdakarya.

Ndraha, T. (1990). Pembangunan Masyarakat Memepersiapkan Masyarakat Tinggal Landas (Community Development Generate to Prepare Community Readiness). Jakarta: Rineka Cipta.

Nuryanti, W. (1993). "Concept, Perspective and Challenges". Makalah bagian dari Laporan Konferensi Internasional mengenai Pariwisata Budaya di Yogyakarta.

Priasukmana, S. (1995). Eco-tourism in Forestry. Supporting paper at the Seminar on Biodiversity. BPPT, 5 - 7 September 1995. Jakarta. Indonesia. 


\section{Macrothink}

Journal of Social Science Studies

ISSN 2329-9150 2018, Vol. 5, No. 1

Putra, I Nyoman Darma dan I Gde Pitana. (2010). Pariwisata Pro-Rakyat Meretas Jalan Mengentaskan Kemiskinan di Indonesia (Tourism Pro- Community paved the Way in Addressing Poverty in Indonesia). Jakarta: Kementerian Kebudayaan dan Pariwisata.

Putra, M. B. (2015). Partisipasi Masyarakat Dalam Pengendalian Lingkungan Hidup.

Slamet, Y. (1994). Pembangunan Masyarakat Berwawasan Partisipasi. Surakarta: Sebelas Maret University Press.

Sugiyono. (2013). Metode Penelitian Kombinasi (Mixed Mothods) Bandung: Alfabeta.

Sugiyono. (2009). Memahami Penelitian Kualitatif, Bandung: Alfabeta.

UNDP and WTO. (1981). Tourism Development Plan for Nusa Tenggara, Indonesia. Madrid: World Tourism Organization.

\section{Constitutional Laws and Regulations:}

UU No. 32 tahun 2004 (Constitutional Laws Number 32 in 2004).

UU No 6/2014 tentang Desa (Constitutional Laws Number 6 in 2014 about Village).

Buku Pedoman Perwujudan Rintisan Model Desa Berdikari Provinsi Jawa Tengah Tahun 2015 (The Manual Realization Planning of Villages Model of Central Java province Achieve 2015).

Peraturan Menteri Desa, Pembangunan Daerah Tertinggal, dan Transmigrasi Republik Indonesia Nomor 4 Tahun 2015 (Regulation of the Minister of Regional Development of the Village, Left, and Transmigration of the Indonesia Republic Number 4 in 2015).

Peraturan Menteri Desa, Pembangunan Daerah Tertinggal, dan Transmigrasi Republik Indonesia Nomor 5 Tahun 2015 (Regulation of the Minister of Regional Development of the Village, Left, and Transmigration of Indonesia Republic Number 5 in 2015).

Peraturan Menteri Kebudayaan Dan Pariwisata Nomor : KM.18/HM.001/MKP/2011 Tentang Pedoman Program Pemberdayaan Masyarakat Mandiri (PNPM) Mandiri Pariwisataan (Regulation of the Minister of Culture and Tourism Numbers: KM. 18/HM.001/MKP/2011 About Independent Community Empowerment Program Guidelines (PNPM) of Tourism Independently).

\section{Copyright Disclaimer}

Copyright for this article is retained by the author(s), with first publication rights granted to the journal.

This is an open-access article distributed under the terms and conditions of the Creative Commons Attribution license (http://creativecommons.org/licenses/by/3.0/). 